\title{
Nitric oxide levels are not changed in saliva of patients infected with hepatitis $C$ virus
}

\author{
Os níveis de óxido nítrico não estão alterados na saliva de pacientes \\ infectados com o vírus da hepatites $\mathrm{C}$
}

\author{
Fernando N. Tavares ${ }^{1}$, Patricia L. Gonçalves ${ }^{1}$, Simone A.C. Porto ${ }^{1}$, \\ Fausto E.L. Pereira ${ }^{1}$ and Rodrigo Ribeiro-Rodrigues ${ }^{1}$
}

\begin{abstract}
The aim of this investigation was to determine nitric oxide metabolite levels in saliva samples from hepatitis $C$ virus-positive patients in an attempt to test the hypothesis if increased levels of nitric oxide metabolites correlates with the presence of $\mathrm{HCV}$ RNA in saliva. Saliva of $39 \mathrm{HCV}$-positive patients and $13 \mathrm{HCV}$-negative patients, without clinical or laboratorial evidence of liver disease were tested for nitric oxide metabolites. HCV-RNA was detected in serum and saliva by a RT-PCR method and nitric oxide level was determined by evaluation of its stable degradation products, nitrate and nitrite. No differences were found between the concentration of nitrite in saliva from HCV patients and controls, in despite of the presence or not of HCV RNA in saliva. Patients with HCV and cirrhosis had higher concentrations of nitrite but not significantly different from the control group or the groups of anti-HCV patients without cirrhosis. Increased levels of nitrite were not detected in anti-HCV positive patients, an indirect indication that chronic sialoadenitis are infrequent in these patients or occurs with low intensity not sufficient to increase nitric oxide metabolite levels in saliva.
\end{abstract}

Key-words: Hepatitis C. Saliva. Nitric oxide. Sialoadenitis.

\section{RESUMO}

O objetivo desta investigação foi avaliar os níveis de metabólitos do óxido nítrico na saliva de pacientes anti-vírus da hepatite C positivos na tentativa de correlacionar os níveis desses metabólitos com a presença do VHC na saliva. Foram estudados 39 pacientes anti-VHC positivos (9 com enzimas hepáticas normais, 16 com hepatite crônica e 14 com cirrose hepática) e em 13 controles saudáveis, sem sinais ou sintomas de doença hepática.O RNA do VHC foi identificado no soro e na saliva através de técnica de RT-PCR e os níveis de óxido nítrico foram avaliados pela quantificação dos seus metabólitos estáveis, nitratos e nitritos. Os resultados demonstraram que os níveis de nitrito na saliva não diferiram significativamente no grupo anti-VHC positivo em relação ao grupo controle, nem entre os grupo com presença ou ausência do RNA do VHC na saliva. Os níveis de nitrito foram mais elevados no grupo com cirrose hepática do que nos grupos controle e anti-VHC positivos, sem cirrose hepática, mas as diferenças não foram estatisticamente significativas. A não observação de níveis elevados de nitrito na saliva dos pacientes anti-VHC positivos é uma indicação indireta de que a sialoadenite não deve ser freqüente nesses pacientes ou, se existe, é de intensidade não suficiente para modificar os níves de óxido nítrico na secreção salivar.

Palavras-chaves: Hepatite C. Saliva. Óxido nítrico. Sialoadenite.

\footnotetext{
1. Núcleo de Doenças Infecciosas do Centro Biomédico da Universidade do Espírito Santo. Vitória, ES, Brazil. Address to: Prof. Rodrigo Ribeiro-Rodrigues. Núcleo de Doenças Infecciosas/CBM/UFES. Av Marechal Campos 1468, 29040-091 Vitória, ES. Fax: 5527 3335-7206

e-mail: rodrigrr@ndi.ufes.br

Recebido para publicação em 9/1/2004

Aceito em 26/7/2005
} 
Saliva is an organic fluid that can be easily collected without the need for invasive methods. Considering that many components, normally found in serum, are also present in saliva, this fluid has been considered as a surrogate sample for serum/plasma samples in biochemical and immunological analysis. Although having been endogenously produced by salivary glands and excreted in saliva, nitric oxide (NO) may also be produced in small quantities by bacteria present in the oral cavity or be up taken from blood by salivary gland cells ${ }^{2}$. Nitric oxide metabolites have been evaluated in the saliva and it has been shown that their concentration is significantly elevated when oral or salivary inflammatory diseases are present ${ }^{912}$ or after heavy physical exercise ${ }^{14}$; but are known to be reduced among smokers ${ }^{3}$.

Up regulation of the inducible NO synthase 2 gene (iNOS-2), with the over expression of this enzyme by hepatic tissue has been reported in patients with chronic hepatitis $\mathrm{B}$ and $\mathrm{C}^{10}$. In addition, elevated levels of either NO or NO metabolites (nitrites and nitrates) has been demonstrated in plasma, exhaled air and ascitic fluid from patients with liver cirrhosis of different etiologies ${ }^{46716}$. Interestingly, Moussa et $\mathrm{al}^{11}$ reported that NO metabolite levels in serum samples from patients with HCV infection, without cirrhosis, did not differ from healthy control samples in a study of 20 patients and 8 controls, but were significantly lower when compared to samples from patients with HCV infection and cirrhosis and from patients with cirrhosis of other etiologies. These authors concluded that HCV infection does not appear to be responsible for the elevated production of NO in patients with HCV infection and cirrhosis, but the severity of liver injury would be an important factor for the observed increase of NO levels.

Recently, the presence of HCV in epithelial cells of salivary glands of HCV positive patients was demonstrated, reinforcing the hypothesis that this virus is an etiological factor in sialoadenitis ${ }^{1}$. It has also been demonstrated that transgenic mice carrying the HCV envelope genes developed sialoadenitis at a frequency higher than $80 \%$ at the age of six months or older ${ }^{8}$. NO is produced by macrophages in inflammatory lesions and it has been shown that HCV induces iNOS- 2 in hepatic macrophages and epithelial cells ${ }^{10}$. Therefore, it is possible that the presence of HCV in salivary glands may induce focal sialadenitis, accompanied by an increased production of NO by inflammatory cells and/or epithelial cells, which could be detected in saliva.

To test the hypothesis that increased levels of NO metabolites correlates with the presence of HCV-RNA in saliva, we decided to determine NO metabolite levels in saliva samples from HCV-positive patients.

\section{MATERIAL AND METHODS}

Patients. The studied population comprised thirty-nine anti-HCV positive patients ( 5 with normal liver enzymes, 20 with abnormal liver enzymes and chronic hepatitis confirmed by biopsy and 14 with cirrhosis) and 13 anti-HCV negative healthy individuals, without signs and symptoms of liver disease. HCV-RNA was detected in serum samples from 32 out of 39 patients with a positive serology for HCV. In eight patients HCV-RNA was detected in both serum and saliva samples. The presence of anti-HCV antibodies was investigated by commercial ELISA assay kits.

Detection of HCV-RNA in both saliva and plasma. The procedure was performed as described by Oliveira et $\mathrm{al}^{13}$. Briefly, RNA was isolated from saliva and plasma samples and reverse transcribed into cDNA. The cDNA samples were then amplified using nested-PCR specific for HCV. After running the nested-PCR, the presence of amplicons was evaluated by electrophoresis in $8 \%$ polyacrylamide gels stained with ethidium bromide.

Saliva collection. After oral stimulation by chewing a small piece of latex tubing for two minutes, patients were asked to spit on a funnel over a $15 \mathrm{ml}$ Falcon tube until a sample volume of $2-3 \mathrm{ml}$ of saliva was collected. After addition of $2 \% \mathrm{~N}$-acetyl cysteine, saliva samples were centrifuged ( $2000 \mathrm{rpm}$ for 10 minutes), their supernatant collected and stored at $-70^{\circ} \mathrm{C}$ until use.

Evaluation of nitric oxide levels in saliva samples. Nitric oxide levels in saliva samples were determined by evaluation of its stable degradation products, nitrate and nitrite. Nitrate is detected after its reduction to nitrite by nitrate reductase. The assay was performed as described by Rockett et a ${ }^{15}$. A standard curve was established using $\mathrm{NaNO}_{2}$ with a range $10-1000 \mu \mathrm{M}$ for each assay.

Statistical analysis. The EpiInfo 6.0 was used for statistical comparisons. The values for $\mathrm{p}<0.05$, in one tailed tests, were considered significant.

\section{RESULTS}

Nitrite level results in saliva samples for the studied population are depicted in Figures 1 and 2. There was no significant difference between the concentrations of nitrites in the saliva samples from HCV patients with HCV-RNA in saliva when compared to HCV patients without HCV-RNA in saliva or to the control group. Although higher, the nitrite levels in saliva samples from HCV-positive patients with cirrhosis were not significantly different from those from HCV patients with either positive HCVRNA in saliva, or with chronic hepatitis, or asymptomatic with normal liver enzyme levels or from healthy control individuals.

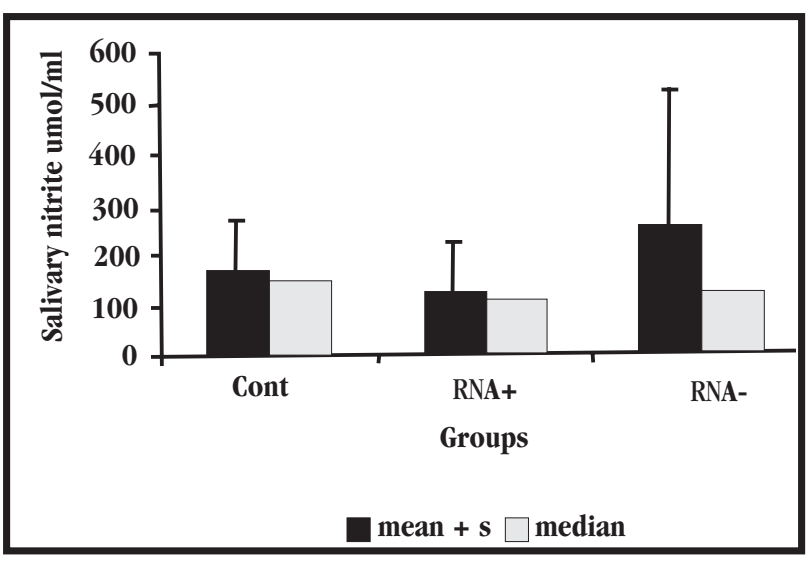

Figure 1 - Salivary nitrite levels in control group $(N=13)$ and in antiHCV+ patients with HCV-RNA present $(N=8)$ or absent $(N=31)$ in saliva. Mann-Whitney test, $\mathrm{p}>0.05$. 


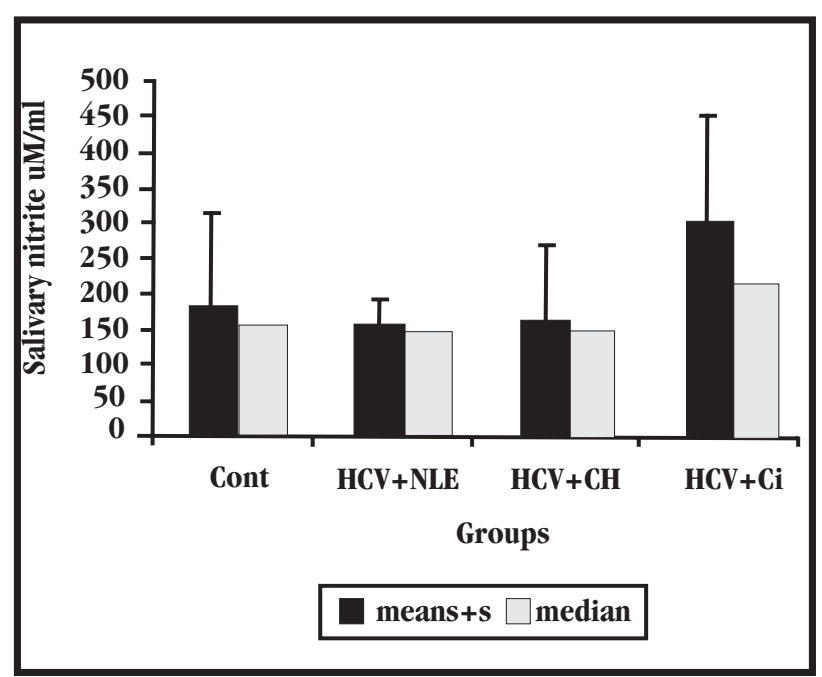

Figure 2 - Salivary nitrite levels in control group $(\mathrm{N}=13)$ and in antiHCV patients classified as asymptomatic, with normal liver enzymes $(\mathrm{HCV}+\mathrm{NLE} ; \mathrm{N}=5)$, chronic hepatitis $(\mathrm{HCV}+\mathrm{CH} ; \mathrm{N}=20)$ or cirrhosis $(H C V+C i ; N=14)$. Mann-Whitney test, $p>0.05$.

\section{DISCUSSION}

A high variation was observed in the nitrite levels in saliva samples from healthy control individuals. The high standard deviation values observed for the calculated mean average reflect the real variation of nitrites in saliva, that include the nitrites originated from NO in airways, mouth and digestive tube.

Our results have demonstrated that the nitrite concentration in saliva samples from HCV patients did nor differ those from HCVnegative patients without signs or symptoms of liver disease that were used as controls. These results corroborate data published by Moussa et $\mathrm{al}^{10}$, who reported similar nitrite levels in serum from HCV positive patients and controls. In addition, as observed by Moussa et al $^{10}$, in serum samples, our results have demonstrated elevated nitrite levels in saliva samples from HCV patients with cirrhosis, even though the observed difference was not significant when compared to the control group or to the HCV positive groups without cirrhosis. These elevated nitrite levels in saliva samples from HCV patients with cirrhosis, may be the result of uptake and excretion of NO from the blood by salivary glands.

The concentration of nitrite in saliva was similar among patients from the HCV positive group, independent of whether HCV-RNA in saliva samples was present or not. Presence of VHC-RNA in saliva samples has been reported at different frequencies, but this variation may be related to the presence of hidden blood traces contaminating saliva samples. VHCRNA was present in $25 \%$ of our cases, with no correlation with the HCV genotype (data not shown).

The presence of VHC-RNA in saliva may or may not be indirect evidence of the presence of HCV infection in salivary glands. To our knowledge, there is only one report demonstrating the presence of double-stranded HCV-RNA in salivary gland epithelial cells from eight HCV positive patients ${ }^{1}$. The absence of symptoms of sialoadenitis such as sicca syndrome among our patients with positive HCV-RNA in saliva, indicates that if the virus is replicating in salivary glands, this replication is not inducing a marked sialoadenitis. In fact, induction of iNOS-2 in salivary glands and the increase in the NO concentration in saliva would follow the presence of chronic inflammation, in a similar manner as demonstrated in HCV associated chronic hepatitis ${ }^{10}$ and in Sjögren's syndrome ${ }^{9}$. An increased level of nitrite in anti-HCV positive patients was not detected in our experiments. This data may be an indirect evidence of absence or reduced chronic sialoadenitis in these patients, even when patients with HCV-RNA present in saliva were considered.

\section{REFERENCES}

1. Arrieta JJ, Rodriguez-Inigo E, Ortiz-Movilla N, Bartolome J, Pardo M, Manzarbeitia F, Oliva H, Macias DM, Carreno V. In situ detection of hepatitis C virus RNA in salivary glands. American Journal of Pathology 158:259-64, 2001.

2. Bodis S, Haregewoin A. Evidence of release and possible neural regulation of nitric oxide in human saliva. Biochemical and Biophysical Research Communications 194:347-350, 1993.

3. Bodis S, Haregewoin A. Significantly reduced salivary nitric oxide levels in smokers. Annals of Oncology 5:371-3722,1994.

4. Bories PN, Campillo B, Azaou L, Scherman E. Long-lasting NO over production in cirrhotic patients with spontaneous bacterial peritonitis. Hepatology 25:1328-1333, 1997.

5. Campillo B, Bories PN, benvenuti C, Dupeyron C. Serum and urinary nitrate levels in liver cirrhosis: endotoxemia, renal function and hyperdynamic circulation. Journal of Hepatology 24:707-714, 1996

6. Garcia-tsao G, Angulo P, Gacia JC, Groszmann RJ, Cadelina GW. The diagnostic and predictive value of ascites nitric oxide levels in patients with spontaneous bacterial peritonitis. Hepatology 28:17-21, 1998.

7. Guarner C, Soriano G, Tomas A, Bulbena A, Novella MT, Balanzo J, Villardel F, Moncada S. Increased nitric oxide levels in patients with cirrhosis: relationship to endotoxemia. Hepatology 18:1139-1143, 1993.

8. Koike K, Moriya K, Ishibashi K, Yotsuyanagi H, Shintani Y, Fujie H, Kurokawa K, Matsuura Y, Miyamura T. Sialadenitis histologically resembling Sjögren syndrome in mice transgenic for hepatitis $\mathrm{C}$ virus envelope genes. Proceedings of the National Academy of Sciences 94:233-236, 1997.

9. Konttinen YT, Platts LA, Tuominen S, Eklund KK, Santavirta N, Tornwall J, Sorsa T, Hukkanen M, Polak JM. Role of nitric oxide in Sjogren's syndrome. Arthritis and Rheumatism 40:875-883, 1997.

10. Majano PL, Garcia-Monzon C, Lopez-Cabrera M,Lara-Pezzi E, FernandezRuiz E, Garcia-Iglesias C, Borque MJ, Moreno-Otero R. Inducible nitric oxide synthase expression in chronic viral hepatitis. Evidence for a virus induced up-regulation. Journal of Clinical Investigation 101:1343-1352, 1998.

11. Moussa YI, Plevris JN, Hayes PC. Plasma nitrites/nitrites in HCV infection and hepatocellular carcinoma. European Journal of Gastroenterology 12:159-163, 2000

12. Ohashi M, Iwase M, Nagumo M. Elevated production of salivary nitric oxide in oral mucosal diseases. Journal of Oral Pathology and Medicine 28:355-359, 1999.

13. Oliveira GC, Carmo RA, Rocha MO, Silva MO, Lima AT, Guimaraes MD, Correa-Oliveira R. Hepatitis C virus genotypes in hemophiliacs in the State of Minas Gerais, Brazil. Transfusion 39:1194-1199, 1999.

14. Panossian AG, Oganessian AS, Ambartsumian M, Gabrielian ES, Wagner $\mathrm{H}$, Wikmans G. Effects of heavy physical exercise and adpatogens on nitric oxide content in human saliva. Phytomedicine 6:17-26, 1999.

15. Rockett KA, Awburna M, Rockett EJ, Cowden WB, Clark IA. Possible role of nitric oxide in malarial immunosuppression. Parasite Immunology 16:243249, 1999.

16. Sogni P, Garnier P, Gadano A, Moreau R, Dall'Ava-Santucci J, Dinn-Xuan AT, Lebrec D. Endogenous pulmonary nitric oxide production measured from exhaled air is increased in patients with severe cirrhosis. Journal of Hepatology 23:471-473, 1995. 